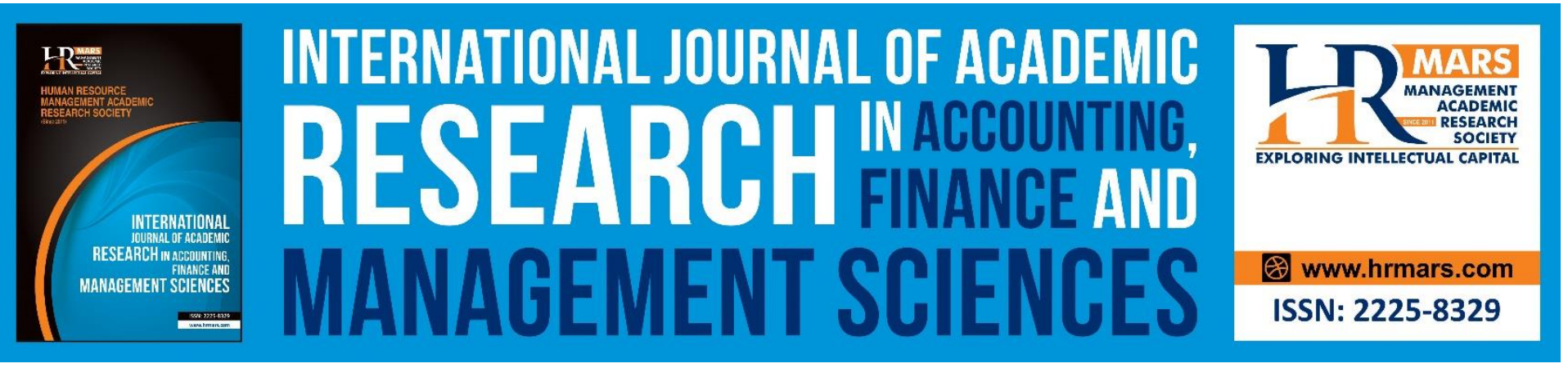

\title{
Factors Affecting Audit Fees in Jordanian Private Sector: From the Point of View of Jordanian External Auditors
}

\section{Ghassan Falah Al- Matarneh}

To Link this Article: http://dx.doi.org/10.6007/IJARAFMS/v10-i3/8099

DOI:10.6007/IJARAFMS /v10-i3/8099

Received: 20 June 2020, Revised: 23 July 2020, Accepted: 21 August 2020

Published Online: 25 September 2020

In-Text Citation: (Al- Matarneh, 2020)

To Cite this Article: Al- Matarneh, G. F. (2020). Factors Affecting Audit Fees in Jordanian Private Sector: From the Point of View of Jordanian External Auditors. International Journal of Academic Research in Accounting, Finance and Management Sciences. 10(3), 389-399.

\section{Copyright: (c) 2020 The Author(s)}

Published by Human Resource Management Academic Research Society (www.hrmars.com)

This article is published under the Creative Commons Attribution (CC BY 4.0) license. Anyone may reproduce, distribute, translate and create derivative works of this article (for both commercial and non-commercial purposes), subject to full attribution to the original publication and authors. The full terms of this license may be seen

at: http://creativecommons.org/licences/by/4.0/legalcode

\section{Vol. 10, No. 3, 2020, Pg. 389 - 399}

Full Terms \& Conditions of access and use can be found at http://hrmars.com/index.php/pages/detail/publication-ethics 


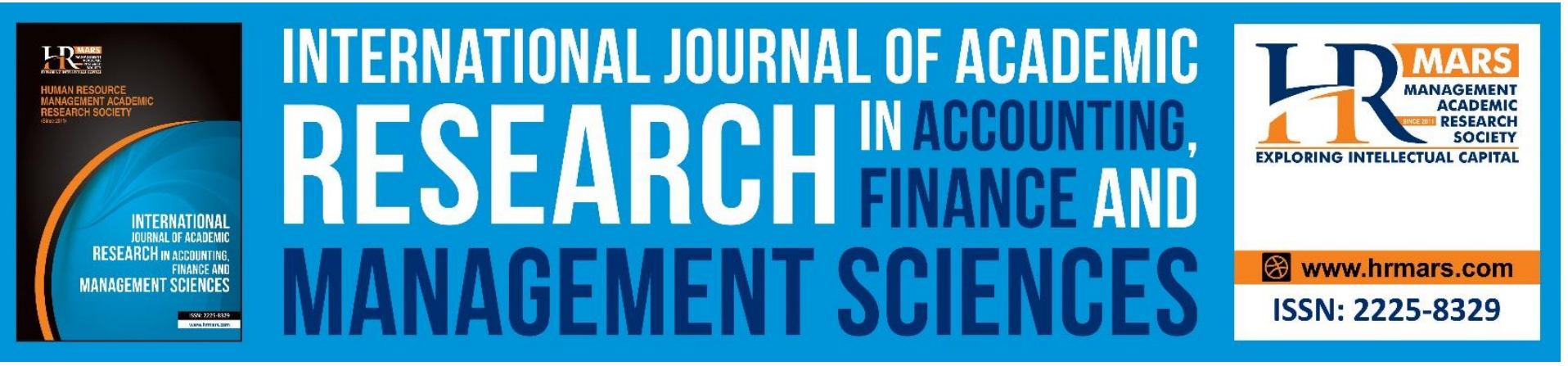

\title{
Factors Affecting Audit Fees in Jordanian Private Sector: From the Point of View of Jordanian External Auditors
}

\author{
Ghassan Falah Al- Matarneh \\ Professor, Al- al-Bayt University, P.O .Box 144170, Zip Code 11814Amman - Jordan \\ Email: dr_matarneh@hotmail.com
}

\begin{abstract}
This study surveys views of Jordanian auditors about how the most important factors affecting the pricing of audit services, provides evidence whether the factors related to the client's corporate, factors related to the audit office. To accomplish these objectives, a questionnaire was designed and distributed to a sample of (235) of Jordanian auditors, To Conduct data analysis descriptive statistics, means, standard deviation were used. The results revealed by this study that the auditor's service pricing is determined by factors related to the client's corporate such as the number of branches and departments of the entity, net flow of operating activities, in addition to the factors related to the audit office such as the audit office subordinated to international office, reputation of audit office. While Jordanian auditors are not consider the office size, Conducting of ethics of accounting profession, and Conducting of mandatory legislation and accounting standards as determinants of audit service pricing.
\end{abstract}

Keywords: Pricing, Audit Service, Jordan, Client, Audit Office.

\section{Introduction}

The audit fees known as the amounts, wages or fees charged by the auditor for an audit process performed for the accounts of an enterprise, the audit fees determined according to the contract which is between the client and the auditor in accordance with the time spent on the audit process, the service required, and the assistants needed for the audit process. And do not forget that the fees are determined before begin the process of auditing and fees must be fair and consistent with the effort that will spend, reputation of the auditor office, and his professional experience, as well as the degree of risk which may be incurred (Al-Matarneh, 2013).

Since more than twenty years the controversy and debate on the audit fees and factors that affect it has been started. There is a growing trend in recent years in accounting thought about discussing this issue. The problem sometimes arises because of the impact of the big audit firms on audit fees, and whether these offices get an increase in the audit fees and what is the reason behind it. Also sometimes the problem occurs because of the impact of advisory services provided by the audit office 
INTERNATIONAL JOURNAL OF ACADEMIC RESEARCH IN ACCOUNTING, FINANCE AND MANAGEMENT SCIENCES

Vol. 10, No. 3, 2020, E-ISSN: 2225-8329 @ 2020 HRMARS

to the customer on the audit fees. On other hand controversy occur because of the different audit fees from one sector to another, as well as many questions occur about the impact of the client's entity size, the complexity of its operations, and the extent of the risk associated with the audit process and its impact on audit fees. Therefore this study aims to provide evidence on the question of whether the audit fees determined by the factors related to the client, and factors related to the audit office. This is achieved by examining the impact of these factors on the audit fees.

The paper is organized as follows. Section 2 provides a review of related literature. Section 3 provides a background of auditing in Jordan. Section 4 provides theoretical framework about audit fees. Section 5 describes the research methodology. Section 6 presents the results of the study, while Section 7 summarizes the study and provides its main conclusions.

\section{Review of Related Literature}

There is now a substantial and growing literature concerned with the multivariate modeling of audit fees. Many of these studies contain common variables, including measures for size, complexity and risk. Several constructs and measures have been used to operationalize each of these variables; therefore the present study focuses on all these factors from the Jordanian auditors' point of view. In this review previous studies are separated into two main categories;

The first covers studies conducted in developed countries and the second covers studies conducted in developing countries.

Rashedi study (2020) examines the similarities and differences between the factors affecting the audit fee of financial statements from the standpoint of independent auditors working in audit firms (managers and senior managers) as well as members of the board of directors, managers and financial assistants of the owners. Factors considered include specific variables of the auditor, and specific variables of the audit work. The results show that there is no significant difference between independent auditors and financial managers in any particular domain of auditor, auditor specific and audit specific.

Ye (2020) says the audit fee refers to the remuneration obtained by accounting firms and auditors for providing professional services. The determination of audit fees re-quires mutual consultation between audited units and accounting firms. In order to ensure the quality of the audit report, as an important part of the auditor incentive mechanism, the establishment of reasonable audit fees is a necessary condition to ensure that the certified public accountants perform the normal information assurance function and ensure the effective operation of the audit work. Audit fee is the price of audit report. As the supplier of audit report and the demander of audit report, the relationship between supply and demand of both parties will inevitably affect audit fee.

Study of Tran et al (2019) investigate the levels of factors influencing audit fees for clients of Vietnamese garment and textile firms from 186 auditors in independent audit firms in Vietnam. The results have shown that customer size, type of professional audited services by the company, the safety of customer's internal control system and the connection between the audit firms with four big international audited firms were the most important factors that determine external audit fees in Vietnamese garment and textile enterprises. On the other hand, factors such as the location of the audited and audit firm, the complexity of the audit process, annual revenues of the audit, and the 
INTERNATIONAL JOURNAL OF ACADEMIC RESEARCH IN ACCOUNTING, FINANCE AND MANAGEMENT SCIENCES

Vol. 10, No. 3, 2020, E-ISSN: 2225-8329 @ 2020 HRMARS

type of report required by the auditing company have appeared to be the least important factors in determining external audit fees in Vietnamese garment and textile enterprises.

According to study of AL-Mutairi et al (2017) which examines the perception of a sample of Kuwaiti external auditors about the importance of various factors that may affect external audit fees. The study found that audit fees in Kuwait are determined by the size of the audited company, type of professional services provided by the audit firm, safety of the audited company's internal control system, and affiliation of the audit firm to big four international audit firms. Factors such as the location of the audit firm and the location of the audited company, complexity of the audited company and type of reports required to be submitted by the audit firm were the least important factors.

Kimeli study (2016) sought to find out the determinants of audit fees in Kenya, the population of the study was drawn from all the firms listed at the NSE throughout the period 2008 to 2014 and their respective auditors; this was informed by the availability of published annual reports by the listed firms in Kenya. Companies whose financial results for the seven years were not available were not analyzed in this study; also companies incorporated out of Kenya were not analyzed due to differences in currency. The researcher targeted annual financial statements of listed firms in 2008 and 2014 financial years. The findings of the study support a link between Audit pricing and: Auditor Experience, Auditor Reputation, Big 4 status; Client size; Client complexity; and the reporting time lag are the important factors determining audit fees for Kenyan listed firms. A negative relationship was found between audit fees and auditor size while no relationship was found between audit fees and: reporting season, client profitability, and client risk.

The research of Kistana (2016) examines factors affecting between board characteristics, audit committee characteristics, audit complexity, audit risk, audit firm size and audit quality which affects the amount of audit fees among Ethiopian private commercial banking industry, With regard to factors that affecting audit fees; all board characteristics, audit committee characteristics, audit quality, audit firm size and audit risk are found to be the major factors influencing the variation in audit fees in the Ethiopian private commercial banking industries. Typically, board and audit committee characteristics and audit qualities are inversely related to audit fee. In addition, the audit risk, audit complexity and audit firm sizes are directly related with the audit fee in the study area. The reason is that, as since liquid assets include currency and coins and cashes associated with ATM operation, which also require more audit effort to count and confirm their balance, then the complexity is increasing so that increases request for higher audit fee

Study of Ma \& Wang (2010) found that a major factor in the annual audit fees is the size of listed companies, place of registration for the economically developed regions, asset-liability ratio; the most critical factor is the size of listed companies. The number of independent directors on the annual audit costs whiles no significant effect.

Naser \& Nuseibeh (2007) investigates the structure of audit fees in an emerging economy by using regression model tested by running across-sectional linear ordinary least squares (OLS) regression of the audit fees on corporate size, the status of the audit firm, the degree of corporate complexity, 
INTERNATIONAL JOURNAL OF ACADEMIC RESEARCH IN ACCOUNTING, FINANCE AND MANAGEMENT SCIENCES

Vol. 10, No. 3, 2020, E-ISSN: 2225-8329 ๑ 2020 HRMARS

profitability, risk, corporate accounting year end and the lag between the audit report and the end of the accounting year. The results of the analysis revealed that corporate size, status of the audit firm, industry type, degree of corporate complexity and risk are the main determinants of audit fees. However, variables such as corporate profitability, corporate accounting year-end and time lag between yearend and the audit report date appeared to be insignificant determinants of audit fees.

\section{Background of Auditing in Jordan}

Jordan is committed to aligning its national corporate financial reporting requirements with the International Financial Reporting Standards and the International Standards on Auditing, and it has achieved significant steps towards achieving this objective, including issuance of a new Accounting Profession Law in 2003. The law sets guidelines on education and experience necessary for certification for public practice, and it also sets penalties to be given to auditors who violate audit laws and regulations. Based on the new law a high commission for the accounting profession was established. It is headed by the Minister of Industry and Trade, and has responsibility for regulating issues related to the accounting profession in Jordan. Its members include the Controller of the Companies in the Ministry of Industry and Trade and representatives from the Central Bank of Jordan, the Jordan Securities Commission, the Insurance Commission, and the Auditing Bureau, in addition to three elected auditors and one academic specializing in accounting. The High Commission of the Accounting Profession requires auditors to apply International Standards on Auditing (Al-Matarneh, 2013).

Monitoring auditors' performance is generally not rigorous in Jordan. However, international audit firms which have affiliated audit firms in Jordan do practice their own monitoring and peer review in order to enhance the quality of their international audits.

The system governing the audit profession in Jordan has a number of shortcomings. For example, the World Bank (2004) states that although JACPA has responsibility to draft its own by laws and has disciplinary authority over its members; it lacks resources to function properly as an effective professional accountancy body. The World Bank (2004) also reports that JACPA lacks effective monitoring and enforcement mechanisms to ensure that auditors follow auditing standards and the code of ethics issued by the International Federation of Accountants (IFAC). This view is, to some extent, confirmed, for example, by JACPA's self-assessment questionnaire (IFAC, 2006), where it reports that although it has a quality control system in place to monitor member audit firms, such quality control checks have never been made. The questionnaire does not show details of any other actual cases of enforcement of any laws or monitoring their application.

The World Bank (2004) also reports several problems facing the audit profession in Jordan. These include poor auditor independence (due to heavy reliance on few clients and strong personal relations with clients), poor following of audit procedures concerning related parties (especially important given the dominance of the family business system), poor use of external confirmation, poor use of the audit report (such as not qualifying it for departure from accounting standards), heavy reliance on management representations without obtaining corroborative evidence, and poor compliance with quality control requirements (including continuous education of auditors).

The first auditing firm was established in Jordan in 1944; before that the auditing services were provided through auditing firms in Palestine. The professional codes were taken from British Companies Law, until the issuance of the Jordanian Companies Law 33/1962 (6). Jordanian 
INTERNATIONAL JOURNAL OF ACADEMIC RESEARCH IN ACCOUNTING, FINANCE AND MANAGEMENT SCIENCES

Vol. 10, No. 3, 2020, E-ISSN: 2225-8329 @ 2020 HRMARS

Association of Certified Public Accountants (JACPA) board was founded in 1988 (under Law 42/1987). A new Accountancy Profession Law 73/2003 was issued on June 16, 2003. Important features of the Accountancy Profession Law include the establishment of a "High Council for Accounting and Auditing" headed by the Minister of Industry and Trade, and the creation of an improved (JACPA).

The new Jordan's Companies Law 22/1997 obliges all companies registered under the Companies Law to maintain sound accounting records and present annual audited financial statements in accordance with "internationally recognized accounting and auditing principles." Auditors are elected for one year with the possibility of renewal. The Accountancy Profession Law gives new powers to (JACPA), such as responsibility to draft its laws, disciplinary authority over its own members, and the right to inspect its members' working papers.

In Jordan there are two important laws governing audit practice: The Law of Audit Profession 1985 and The Companies Law 1997. With regard to audit licensing, Article 4 of the Audit Profession Law, 1985 stipulates that in order to be licensed as a professional auditor, the following criteria must be met. The applicant must be a Jordanian citizen, of good moral character, and must meet at least one of the following requirements:

- $\quad$ PhD degree in accounting, with a minimum of one year of practical accounting and auditing experience, or a two-year minimum of teaching experience, or;

- Master's degree in accounting or its equivalent, with a minimum of two-years, Practical accounting and auditing experience, or;

- $\quad$ Bachelor's degree in accounting or its equivalent, with a minimum of three years' practical accounting and auditing experience, or;

- $\quad$ Any holder of a college degree who has adequate experience of seven years or more, or;

- $\quad$ Any holder of a professional qualification from an accredited accounting body, such as AICPA (Al-Matarneh, 2009).

The World Bank report showed that the quality of some audits in Jordan was materially affected by management attitudes in client companies, and severe competition between audit firms. And it is observed that the quality of many audits is affected by management misconception about the valueadded created by audit. Management attitude contributes to the low audit fees. Thus the degree of compliance with the applicable auditing standards varies between large and small firms (Obadiah, 2007).

\section{Factors Affecting the Audfit Service Price}

Based on previous studies and through preliminary interviews with auditors the factors that affecting the pricing of audit services can be classified as follows:

Factors related to the client's corporate: the factors affecting the pricing of audit services with respect to the client company include; the number of branches and departments of the entity, net flow of operating activities, the market value of shares, fiscal year ended of the client (in the peak or late), the value of assets, net profit, the nature of the entity and its revenue and sales, percentage of debtors to assets, the strength of the internal control system, net working capital, rate of return on 
INTERNATIONAL JOURNAL OF ACADEMIC RESEARCH IN ACCOUNTING, FINANCE AND MANAGEMENT SCIENCES

Vol. 10 , No. 3, 2020, E-ISSN: $2225-8329$ @ 2020 HRMARS

assets, the sector which the company belongs to, net operating cash flows, the nature of ownership (private - joint), percentage of inventory to assets.

Factors related to the auditor's office: the factors affecting the pricing of audit services with respect to the auditor's office include; The audit office subordinated to international office, reputation of audit office, number of assistants needed for the audit, auditor's assessment of risks, specialty audit office in a particular sector, advisory services provide by the audit office, skill necessary to carry out the audit, annual revenues of the audit office, audit office size, number of customers who audit their accounts, the length of the contract between the audit office and the entity, competition among audit offices, , the period between the date of contracting and the date of audit report, conducting of ethics of accounting profession, conducting of mandatory legislation and accounting standards.

\section{Research Methodology and Questions Research Methodology}

The research depended on the method of analytical statistics and analysis of content, and on secondary and primary data. Secondary data for the study were obtained through reference, research, and universities research papers. For the initial data, they were collected through a questionnaire, which is designed depending on the nature of the elements of the problem which is available in literature reviews. The statistical descriptive style analysis technique also the content analysis has been used to achieve the objectives of the study. The survey questionnaire contains two parts, first part included demographic characteristics, the second part covers the responders' commitment, each set questions formed a field paragraph, which covers the questions of the study. Five- Likert scale has been used as a measure of reflect the views of respondents regarding the paragraphs contained in the questionnaire, which was allocated weight (5) for the situation strongly agree, and (4) for agree, and (3) for the situation is neutral and (2) for disagree, and (1) for Strongly Disagree. the questionnaire has introduced to a group of professionals and professors for the purpose of arbitration, where they can modify it based on their observations and a previous test was conducted on it, and the amount of Cronbach's alpha were reached (\%78.45), which is indicated on the consistency and steadfastness (Sekaran, 2016). And arithmetic mean, standard deviation and percentages were used in the quarterly analysis of the responses to the questionnaire.

\section{Research Questions}

Research seeks to answer the following questions:

1. Do the factors associated with the client's corporate affect the pricing of audit services?

2. Do the factors associated with the audit office affect the pricing of audit services?

\section{Sample of Auditors and Data Collection}

The study population consists of the licensed Jordanian external auditors by the end of the year (2010), of the sum of (486) auditor, according to Jordanians Chartered Accountants Association, random sample were selected, representing (50\%) of the study population, (242) questionnaire were distributed, (235) of them recovered and valid for analysis, and thus the percentage of the collected questionnaires to the population were (\%48.4). 
INTERNATIONAL JOURNAL OF ACADEMIC RESEARCH IN ACCOUNTING, FINANCE AND MANAGEMENT SCIENCES

Vol. 10, No. 3, 2020, E-ISSN: 2225-8329 @ 2020 HRMARS

\section{Results of the Study}

The demographical characteristics are described for the respondents and analyze their opinions and responses on the survey questionnaire, and the arithmetic means and standard deviations were extracted from their responses for each field of the questionnaire table (1) shows that 180 respondents or 76.6 percent hold a bachelor degree,25 respondents or 10.7 percent hold Higher Diploma, and 30 respondents or 12.7 percent have a master certificate, As for the area of study, the overwhelming majority of the respondents 78.7 percent have an academic degree in accounting, and 10.7 percent have finance, also10.7 percent have business administrative certificate. The job level for respondents reveal that 20.4 percent partner, 55.3 percent are senior auditors, and 24.3 percent auditors .It can also be seen from the table that the majority of responders 63 percent have had experience for more than ten years. Overall, the table information indicates that they are qualified to answer the questionnaire and can be trusted in their abilities and information.

Table 1. Demographic distribution of the respondents

\begin{tabular}{lcc} 
Variable & Variable Categories & Frequency \% \\
\hline Bachelor's Degree & 180 & 76.6 \\
Higher Diploma & 25 & 10.7 \\
Master's Degree & 30 & 12.7 \\
Accounting & 185 & 78.7 \\
Finance & 25 & 10.7 \\
Business Administrative & 25 & 10.7 \\
Partner & 48 & 20.4 \\
Senior Auditor & 130 & 55.3 \\
Auditor & 57 & 24.3 \\
less than 5 years & 24 & 10.2 \\
From 5-10years & 63 & 26.8 \\
From 10-15years & 96 & 40.8 \\
More than 15 years & 52 & 22.2
\end{tabular}

Table (2) points out the arithmetic mean of the paragraphs that reflect the effect of factors associated with the client's corporate on the pricing of audit services provided by the auditor. The highest arithmetic mean were for the number of branches and departments of the entity reached to (4.1660), and the standard deviations were (.71171), followed by net flow of operating activities as the arithmetic mean reached to (4.1021), and the standard deviations were (.77776). The lowest mean were for the factor of percentage of inventory to assets, the arithmetic mean reached to (2.7277), and the standard deviations were (1.18497) that is mean this factor does not affect the pricing of audit services.The arithmetic means of the respondent's answers of this field are reached to (3.6241), and the standard deviations were (.24211) which means that the respondents believe that factors related to the client's corporate effect the pricing of audit services. 
INTERNATIONAL JOURNAL OF ACADEMIC RESEARCH IN ACCOUNTING, FINANCE AND MANAGEMENT SCIENCES

Vol. 10, No. 3, 2020, E-ISSN: 2225-8329 @ 2020 HRMARS

Table 2: Factors related to the client's corporate

\begin{tabular}{|c|c|c|c|}
\hline Paragraph & Mean & S D & $\begin{array}{c}\text { Significance } \\
\text { Degree }\end{array}$ \\
\hline The number of branches and departments of the entity & 4.1660 & .71171 & 1 \\
\hline Net flow of operating activities & 4.1021 & .77776 & 2 \\
\hline The market value of shares & 4.0979 & .83908 & 3 \\
\hline The client's business complexity & 4.0936 & .89619 & 4 \\
\hline Net profit & 3.8511 & .80007 & 5 \\
\hline The nature of the entity and its revenue and sales & 3.6043 & 1.19149 & 6 \\
\hline Fiscal year ended of the client (in the peak or late). & 3.5830 & .81945 & 7 \\
\hline Risks of the client & 3.5702 & .98187 & 8 \\
\hline The strength of the internal control system & 3.5617 & .67891 & 9 \\
\hline Net working capital & 3.5574 & .85228 & 10 \\
\hline Rate of return on assets & 3.5149 & .82870 & 11 \\
\hline The sector which the company belongs to & 3.4596 & 1.04261 & 12 \\
\hline Net operating cash flows & 3.3447 & .65071 & 13 \\
\hline The nature of ownership (private - joint) & 3.1277 & .88716 & 14 \\
\hline Percentage of inventory to assets & 2.7277 & 1.18497 & 15 \\
\hline Total Field & 3.6241 & .24211 & \\
\hline
\end{tabular}

Table (3) points out the arithmetic mean of the paragraphs that reflect the effect of factors associated with the audit office on the pricing of audit services provided by the auditor. The highest arithmetic mean were for the subordinating of audit office to international office reached to (3.9532), and the standard deviations were (.74675), followed by reputation of audit office as the arithmetic mean reached to (3.9277), and the standard deviations were (1.01225). The table shows that annual revenues of the audit office, the reliance of the auditor on the internal auditor, and the number of customers who audit their accounts does not affect the pricing of audit services, the lowest mean were for this factor reached to (2.1617), and the standard deviations were (.76196). The arithmetic means of the respondent's answers of this field are reached to (3.3098), and the standard deviations were (.34426) which means that the respondents believe that factors related to the audit office effect the pricing of audit services. 
INTERNATIONAL JOURNAL OF ACADEMIC RESEARCH IN ACCOUNTING, FINANCE AND MANAGEMENT SCIENCES

Vol. 10, No. 3, 2020, E-ISSN: 2225-8329 @ 2020 HRMARS

Table 3: Factors related to the Audit office

\begin{tabular}{|l|r|r|c|}
\hline Paragraph & Mean & S D & $\begin{array}{c}\text { Significance } \\
\text { Degree }\end{array}$ \\
\hline The audit office subordinated to international office & 3.9532 & .74675 & 1 \\
\hline Reputation of audit office & 3.9277 & 1.01225 & 2 \\
\hline Number of assistants needed for the audit & 3.9191 & .82551 & 3 \\
\hline $\begin{array}{l}\text { The length of the contract between the audit office and } \\
\text { the entity }\end{array}$ & 3.8340 & .87834 & 4 \\
\hline Auditor's assessment of risks & 3.7957 & .91567 & 5 \\
\hline Specialty audit office in a particular sector & 3.7447 & .90743 & 6 \\
\hline Competition among audit offices & 3.6000 & 1.08683 & 7 \\
\hline $\begin{array}{l}\text { The period between the date of contracting and the date } \\
\text { of audit report }\end{array}$ & 3.5106 & .92155 & 8 \\
\hline Advisory services provide by the audit office & 3.4128 & 1.13032 & 9 \\
\hline Skill necessary to carry out the audit & 3.3447 & .96317 & 10 \\
\hline Conducting of ethics of accounting profession & 2.7149 & .78962 & 11 \\
\hline Annual revenues of the audit office & 2.6383 & 1.16622 & 12 \\
\hline $\begin{array}{l}\text { Conducting of mandatory legislation and accounting } \\
\text { standards }\end{array}$ & 2.5830 & 1.01512 & 13 \\
\hline Audit office size & 2.5064 & .89333 & 14 \\
\hline Number of customers who audit their accounts & 2.1617 & .76196 & 15 \\
\hline Total Field & 3.3098 & .34426 & \\
\hline
\end{tabular}

\section{Results and Recommendations}

\section{Results}

The study came up with some results as follows:

1- There are a number of factors related to the client that affect the determination of audit fees in Jordan.

It shows the most influencing factors are the number of branches and departments of the entity, net flow of operating activities, the market value of shares, and the client's business complexity. The study results are consistent with the study of AL-Mutairi et al (2017), study of Naser \& Nuseibeh(2007), and the study of Kimeli study(2016).

2-There are many Factors related to the audit office affected the determination of audit fees in Jordan.

The most influencing factors are, the audit office subordinated to international office, Reputation of audit office, and number of assistants needed for the audit, this result consistent with result of Naser \& Nuseibeh (2007).

3. The results, do not provide significant evidence of the expected relation between external audit fees and the conducting of ethics of accounting profession, annual revenues of the audit office, conducting of mandatory legislation and accounting standards, audit office size, as factors determine the audit service pricing, this is consistent with the study of Study of Tran et al (2019). 
INTERNATIONAL JOURNAL OF ACADEMIC RESEARCH IN ACCOUNTING, FINANCE AND

MANAGEMENT SCIENCES

Vol. 10 , No. 3, 2020, E-ISSN: $2225-8329$ @ 2020 HRMARS

\section{Recommendations}

1. Jordanian private sector are advised to focus on those factors deemed to have significantly associated with audit fees, by understanding how these variables affect audit fees.

2. We suggest that the Jordanian External Auditors Association fix the minimum and maximum audit fees.

3. Paying attention on the audit fees because of their impact on the independence of the auditor and the quality of the audit.

\section{Limitation of the Study}

Similar to other studies, this study has its limitations. The most important is that the most of the certified auditors in Jordan are those who work in small firms. The population should have aimed at auditors with ample experience, not auditors with low experience. While many experienced Jordanian auditors work for large or international firms, and do not have Jordanian certification (but aim at international certifications).

\section{References}

Al-Matarneh, G. (2013). Auditing -An integrated Approach, 2nd Ed, Amman: Dar Al-Maseerah for publication.

Kistana, G. (2016). Factors Affecting Audit Fees in Private Commercial Banking Industries: In Ethiopia, Unpublished paper submitted to the Department of Accounting and Finance College of Business and Economics, Addis Ababa University.

Rashidi, H. (2020). A Comparative Study of the Factors Affecting the Audit Fees of Financial Statements from the Perspective of Independent Auditors and Chief Executive Officers,SSRN Electronic Journal,January16, 2020, DOI: 10.2139/ssrn.3520633

International Federation of Accountants. (2006). Response to the IFAC Part 2, SMO Self-Assessment Questionnaire: Jordanian Association of Certified Public Accountants, Jordan', December. http:// www.iasplus.com/country/jordan.htm

Ma, L., \&Wang, Z. (2010). The Analysis of Factors Affecting Audit Fees based on Listed Companies in China Biopharmaceutical, Science Technology and Industry Journal,2, http://dx. doi: CNKI: SUN: CYYK.0.2010-02-026.

Naser, K., \& Nuseibeh, R. (2007). Determinants of audit fees: empirical evidence from an emerging economy, International Journal of Commerce and Management,17,(3),239-254, http://dx. doi: $10.1108 / 10569210710833635$.

Obadiah, A. (2007). Auditors' compliance with International Standards on Auditing (ISAs): evidence from Jordan, Journal of Social Sciences Publisher, 3, (4), 185-189, http://dx. doi: 10.3844/jssp.

Sekaran, U., \& Bougie,R. (2016). Research Methods for Business: A Skill Building Approach, 7th Ed, New York: John Wiley and Sons.

World Bank. (2004). Report on the Observance of Standards and Codes (ROSC): Hashemite Kingdom of Jordan: Accounting and Auditing'. http:// www.worldbank.org/ifa/rosc_aa_jor.pdf.

Xin, Ye. (2020). Literature Review on Influencing Factors of Audit Fees. Modern Economy, 11, 249260. https://doi.org/10.4236/me.2020.112022. 